\title{
The Influence of Spiritual Leadership on Organizational Culture at Bank Syariah Mandiri Branch Office and Sub Branch Office Depok
}

\author{
Abdul Jabbar ${ }^{1}$ \\ Retno Kusumastuti ${ }^{2}$
}

\begin{abstract}
This research aims to examine and analyze the influence of spiritual leadership on organizational culture implemented by Bank Syariah Mandiri (hereinafter will be referred as "BSM") Branch Office and Sub Branch Office Depok. Spiritual leadership can be measured by using the concept of spiritual leadership developed by Fry (2003) with five dimensions, namely: vision, altruistic love, hope/faith, meaning/calling, membership, and organizational culture as measured by the ETHIC (Excellence, Teamwork, Humanity, Integrity, and Customer Focus) dimensions in Bank Syariah Mandiri's organizational culture. This research utilized a quantitative approach wherein research data were collected through survey conducted to all employees in the BSM Branch Office and Sub Branch Office Depok, with 55 respondents being involved in this research. The research data were subsequently analyzed by using descriptive statistics analysis and simple linier regression analysis. The results of this research show that spiritual leadership of the Head of BSM Branch Office Depok has a 56 percent positive effect on the implementation of ETHIC organizational culture in BSM.
\end{abstract}

\section{Keywords:}

spiritual leadership; organizational culture.

\begin{abstract}
Abstrak
Penelitian ini bertujuan untuk menguji dan menganalisis pengaruh kepemimpinan spiritual terhadap budaya organisasi yang dilaksanakan oleh Bank Syariah Mandiri (BSM) Kantor Cabang dan Sub Kantor Cabang Depok. Kepemimpinan spiritual dapat diukur dengan menggunakan konsep kepemimpinan spiritual yang dikembangkan oleh Fry (2003) dengan lima dimensi, yaitu: visi, cinta altruistik, harapan, makna, keanggotaan, dan budaya organisasi yang diukur oleh ETHIC (Excellence, Teamwork, Humanity, Integrity, and Customer Focus) dalam budaya organisasi Bank Syariah Mandiri. Penelitian ini menggunakan pendekatan kuantitatif dimana data penelitian dikumpulkan melalui survei yang dilakukan kepada seluruh karyawan di Kantor Cabang BSM dan Kantor Cabang Pembantu Depok, dengan 55 responden dilibatkan dalam penelitian ini. Data penelitian selanjutnya dianalisis dengan menggunakan analisis statistik deskriptif dan analisis regresi linier sederhana. Hasil penelitian ini menunjukkan bahwa kepemimpinan spiritual Kepala BSM Kantor Cabang Depok memiliki efek positif 56 persen terhadap pelaksanaan budaya organisasi ETHIC di BSM.
\end{abstract}

\section{Kata Kunci:}

kepemimpinan spriritual; budaya organisasi.

\footnotetext{
${ }^{1}$ Business Administration, Department of Administrative Science, Faculty of Social and Political Sciences, Universitas Indonesia

Email: abdul.jabbar11@ui.ac.id

2 Business Administration, Department of Administrative Science, Faculty of Social and Political Sciences, Universitas Indonesia
} 


\section{Introduction}

Maintaining potential human resources to remain in the company and provide their best contribution can be achieved through various means, such as by providing promising compensation, a variety of benefits, adequate facilities, or by having a conducive and enjoyable working atmosphere. Speaking of work atmosphere, this consequently refers to organizational culture of the organization/ company itself. Organizational culture is a substantial point of discussion particularly in the context of organizational behavior because culture has the capacity to provide a clear identity for the employees and differentiate one organization from another.

A journal article presented by Seed Bakhsi and Younes Shahbazi under the title "Inquiry of the Relationship between Organizational Culture and Spiritual Leadership in Governmental Organizations in Kermanshah", states that organizational culture was initially introduced in 1979 by Andrew Pettigrew in a paper titled "Study of Organizational Culture". Pettigrew asserted that culture is a group of concepts which includes symbol, language, ideology, belief, religion, and myth. These symbols are then observed through the visual means that organization utilize. The culture subsequently becomes values believed by all members of the company and it is studied, applied, and developed continuously, while functioning as a binding system which is viable as a behavioral reference for the company in achieving its determined goals and objectives. Researches on organizational culture and leadership practices remain to be an interesting topic of research.

According to Fry (2003) spiritual leadership is necessary as a transformation process in continuing the success of learning organization. Spiritual leadership pushes towards fundamental needs required by both leaders and followers in order for them to become more committed and productive in running organizational activities. Fry (2003) states that previous leadership theories merely focused on some aspects of physical, mental, and emotional elements of human interaction within the organization whilst negating its spiritual element. The spiritual concept in this case is meant to be an interpretative understanding of values, attitudes and behavior. Spiritual leadership theory clearly combines, specifically and theoretically, the concept of leadership and the strong desire of its followers with organizational effectiveness and culture into one frame of mind- something which had not been done in previous leadership theories. Concurrently, by combining the understanding of life and participation as well as appreciation in organizational membership as two dimensions of spiritual endurance, spiritual leadership also has values related to religiosity and ethics as its core. Discussions on spiritual leadership cannot be isolated from the work place which undoubtedly bears nuances of spirituality.

Leadership style and organizational culture are concepts of organizational behavior which apply to various business aspects, be it trade, manufacturing, or sharia compliant business. Sharia compliant businesses prioritize values of Islamic sharia in its activities, which is evident in its organizational culture, values, and products. One of the sharia compliant businesses currently developing in Indonesia is banking. The development potential of sharia banking in Indonesia is in reality quite significant, based on Bank Indonesia data, it is recorded that assets of sharia banking as of October 2013 had increased to 229.5 trillion rupiahs. When that number is added with the asset of Sharia Local/Rural Bank (Bank Perkreditan Rakyat - BPR Syariah), then the total asset of sharia banking would amount to 235.1 trillion rupiahs. The growth of sharia banking is quite impressive as it even reached an asset growth rate of over $65 \%$ per year in the last five years. Hence, currently the 
development of sharia banking businesses is regarded as a preferable business sector by potential human resources intending to join in this field.

One of the sharia banking industries that has experienced numerous successes in Indonesia is Bank Syariah Mandiri (BSM). This is evident from the various awards BSM had garnered, such as: "Top Brand Award 2014 Category Sharia Bank" from the Marketing Magazine in collaboration with Frontier Consulting Group; "The Best Islamic Bank in Indonesia 2014" from Euromoney, "The Most Profitable Islamic Full Fledge Bank 2014: Equity IDR > 1 Trillion" from Karim Business Consulting, and others. BSM, which was established in 199, highlighted the principle of "spirituality at work" in its activities. Bank Syariah Mandiri, as a role model for sharia banking in Indonesia, has various facilities for the spiritual development of all employees, which can be conducted through routine religious sermon and study, collective prayer before work, social event agenda, and others. Bank Syariah Mandiri also possesses quite a strong organizational culture wherein BSM emphasizes on spiritual based culture and implements it throughout all of its working divisions.

Based on the background explanation above, the question to be studied in this research is as follows: Is there influence of spiritual leadership on organizational culture at Bank Syariah Mandiri Branch Office and Sub Branch Office Depok?

\section{Theoretical Review}

There are numerous definitions on organizational culture presented by management gurus. According to Robbins, organizational culture is a system of values and beliefs collectively adhered to by organizational members which differentiates one organization from another (Robbins, 2003). Based on that understanding, there are seven dimensions in observing organizational culture, namely: innovation and courage to take risks, attention to detail, result oriented, people oriented, team oriented, aggressiveness, and stability.

Another opinion on the definition of organizational culture is presented by Kotter (1997, p.6) who states that company culture is values and practices mutually shared throughout all the groups in a company, or at least among senior management. The ideas found in a company is often referred to the initial leader or founder, and they are commonly formulated as "vision", "business strategy", "philosophy" or all three.

The following opinion is from Schein (1985) who provides a definition by capturing the essence, complexity and uniqueness of organizational culture. In Schein's opinion, organizational culture is

"a pattern of shared basic assumptions invented, discovered, or developed by a given group as it learns to cope with its problems of external adaptation and internal integration - that has worked well enough to be considered valid and, therefore, to be taught to new members as the correct way to perceive, think and feel in relation to those problems".

Culture has several functions in an organization. Firstly, it serves as a determiner of limits, meaning culture creates differences or distinctions between one organization and another. Secondly, it contains the organization members' feeling of identity. Thirdly, culture paves the way for a commitment to something even greater than sheer individual interests. Fourthly, culture increases social system stability. Culture is the social glue which facilitates in uniting an organization by providing standards regarding what should be said and done by employees, and lastly culture serves as a control and sense-making mechanism which guides and shapes the employee's attitude and behavior. (Robbins, 2003). In essence, organizational culture of an organization may be extremely different 
to another organization, but basically organizational culture demonstrates particular attributes or characteristics which show their similarities. The term used by experts to show these organizational culture characteristics varies. This shows that characteristics, attributes and elements found in organizational culture highly vary.

Wibowo's book (2010) quoting the statement of Michael Zwell (2000:63) regarding characteristics of organizational culture, states that it covers: learned culture, norms and customs are common in all culture, most culture work unconsciously, the nature and characteristics of culture is controlled through numerous social processes and mechanisms, the elements of culture are passed on from one generation to the next, adapting acceptable behavior patterns and customs tends to relate to superiority and moral wisdom, and, other habits, cultural behaviors are comfortable and publicly known.

Hofstede (1991) divides culture characteristics into five aspects, which are: power distance, a level where power distribution is unequal, accepted by people into culture (high power distance) or rejected by them (low power distance); Individualism versus collectivism, individualism is a cultural characteristic in which a person pays more attention to herself and her close family members. As for collectivism, it shows a cultural characteristic which is oriented for the sake of the group; quantity of life versus quality of life, quantity of life is an attribute of national culture which explains the level where social value is signified by determinism and materialism. Quality of life emphasizes on relationships and it pays attention to other people; Uncertainty avoidance, is a stage in which people of a culture feel used and they attempt to avoid unclear situations; Longterm versus short-term orientation, long-term orientation is a national culture attribute which underscores the future, frugality, and diligence.
As for short-term orientation, it stresses on the past and present, honoring tradition and fulfilling social obligations.

These characteristics provide an illustration that culture possesses characters according to those providing its definition and understanding in the organization's activities, hence it is of no surprise that each organization has its own culture as essentially it is this very culture that becomes the special mark of the organization in conducting its activities, as a role model of values and behaviors determined by all organization members. Bank Syariah Mandiri defined their organizational culture with the vigor of "Spiritual Foundation" which focuses on work professionalism elements with foundational basis in strong spiritual activities. This is realized in five core values of Bank Syariah Mandiri, widely known as "ETHIC" (Excellence, Teamwork, Humanity, Integrity, and Customer Focus).

Spirituality leadership talks about the basic needs of leaders and followers regarding aspects of spirituality (spirituality survival) in order for the organization to become more productive and committed. Spiritual leadership is regarded as a necessary value, attitude, and behavior to intrinsically motivate a person's self and others so they could elicit a feeling of spiritual need through their membership in the organization (Fry, 2003). This requires the following:

1. Creating a vision in which organization members undergo meaningful experiences;

2. Determining organizational culture based on altruistic love wherein leaders and followers have mutual feelings of membership, understanding and appreciation, and true concern, focus, as well as appreciation towards the self and others.

Spiritual leadership theory develops internal motivation which combines several indicators. First is vision, which is how a 
leader should have a clear objective for later determining future organizational continuity. Next is hope/faith, hope will eventually become a source of faith for organization to achieve its desired goals. The following indicator is altruistic love, this embodies a feeling of harmony, care, and appreciation towards one's self and others. Next is regarding spirituality at work which emphasizes on how spiritual experiences are acquired in the work environment, as well as spirituality survival which discusses how a person can increase their spiritual aspect through their membership in the organization and allotment of tasks given by the company.

Fry (2005) broadened the theory of spiritual leadership by digging the concept of positive human health and behavior through development of spirituality at the work place, ethical character, positive psychology, and spiritual leadership. The value of a leader, the attitude and behavior reflected in the vision of the organization will demonstrate how much effort the employees put in and how much reward is given to them within an organization. In this case, the effort signifies the dimension of hope/faith, and reward signifies the dimension of altruistic love. These values (vision, hope/faith, altruistic love) will influence the employee's need in the spiritual aspect, that is the calling/meaning in working and membership (the need to be understood and appreciated).

\section{Vision}

One of the most important element is a clear vision regarding where an organization wants to be in the future. Vision is not often used in leadership literature up to the 1980s. Vision leads up to a future illustration with a number of implicit and explicit comments regarding why people should strive in creating the future. (Kotter, 1996, p.68). Vision presents three substantial functions, namely: it clarifies general direction towards change; it simplifies hundreds even thousands of detailed decisions; and it promptly and effectively facilitates in coordinating actions of numerous distinctive individuals.

\section{Altruistic Love}

This terminology, which is often likened to charity, has values containing feelings related to unselfishness, loyalty, wisdom, attentiveness, and appreciation towards the self and others. The personal outcomes of altruistic love are happiness, peace, and tranquility. These outcomes also pose as a source in observing the level of organizational commitment, productivity, and in reducing stress level which is the goal of most managers and organizations.

\section{Hope/faith}

Trust or faith is more than just hoping or the like. It is based on values, attitudes and behavior demonstrating strong conviction and faith in what is desired and the expectation of obtaining it. People with hope or faith have a vision of where they are heading, how they will get there, and they expect to meet challenges and go through difficulties in achieving their goals. (MacArthur, 1998). Hope/faith is a source of conviction for realizing the vision, goals and mission of the organization.

\section{Meaning/Calling,}

Meaning/Calling explains that each organization member trusts and believes that the work they do is important and has significant meaning to them. This would also provide a difference in one's life.

\section{Membership,}

The organization understands and appreciates every action and achievement accomplished by its employees. 


\section{Research Methodology}

Figữe 1. Rensearch M̂́ỏèl

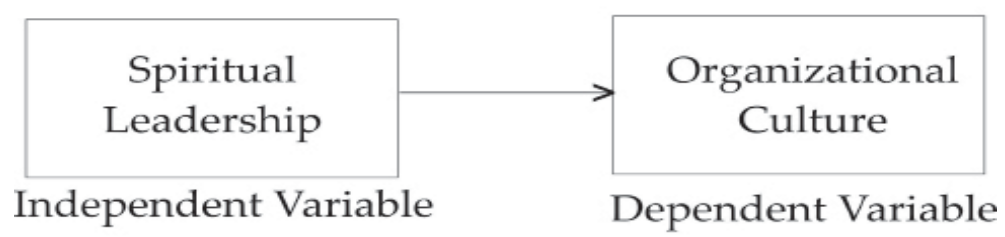

Made by the researchers (2015)

The above research model illustrates the influence that leadership variable has on organizational culture. Based on the research model above, the hypothesis of the study is as follows $\mathrm{H} 0=$ There is no influence of spiritual leadership on organizational culture at Bank Syariah Mandiri Branch Office and Sub Branch Office Depok, H1 = There is influence of spiritual leadership on organizational culture at Bank Syariah Mandiri Branch Office and Sub Branch Office Depok.

\section{Measurement of Variables}

Spiritual leadership was measured using the five dimensions presented by Fry (2003). These dimensions are vision, altruistic love, hope/faith, meaning/calling, and membership. As for the dimension of organizational culture, Bank Syariah Mandiri's organizational culture dimensions were used, namely ETHIC (Excellence, Teamwork, Humanity, Integrity, Customer Focus). Measurement was conducted through survey by using a 6 point Likert scale, from strongly disagree to strongly agree. The validity and reliability of all the statement items in the research questionnaire have been tested, wherein the Pearson Product Moment $\left(\mathrm{r}_{\text {count }}\right)$ for each item statement was greater than $0.261\left(\mathrm{r}_{\text {table }}\right)$ and the Cronbach's alpha for each statement item was greater than 0,6 (Sekaran, 2000).

\section{Type of Research}

This research utilized a quantitative approach by obtaining data that are generally acquired through structured questionnaires in the form of numbers or quantified qualitative data. A research approach refers to a perspective in studying social phenomenon which is founded on a basic assumption and which explains how a social phenomenon occurs and how social issues or problems appear (Cooper and Schindler, 2001). Regarding its benefit, this study is pure research, meaning that it is conducted to further develop knowledge theoretically by analyzing a particular social problem (Cooper and Schindler, 2001). In terms of time point, this is a cross-sectional research which analyzes data collected at a specific point in time. This study was undertaken to understand the influence of spiritual leadership on organizational culture at Bank Syariah Mandiri Branch Office and Sub Branch Office Depok within a one-month survey and questionnaire distribution period from the month of February to March 2015.

\section{Population and Sample}

The population of this research was all of the permanent employees working at Bank Syariah Mandiri Branch Office and Sub Branch Office Depok. A total sampling technique was used in this study due to the similar amount and relatively small number of population and sample. As much as 80 questionnaires were distributed to employees working at Bank Syariah Mandiri Branch Office and Sub Branch Office Depok, of which 55 questionnaires were returned to the researcher. Total sampling means taking the entire population as a part of the research sample (Notoatmodjo, 2002). The 
use of this technique is meant to gain a holistic illustration and understanding regarding spiritual leadership and organizational culture at Bank Syariah Mandiri Branch Office and Sub Branch Office Depok.

\section{Data Collection Technique}

The data collection technique utilized in this study is meant to obtain relevant and accurate data on the subject matter. The data collection technique used in this study is founded on a quantitative approach wherein the data used are those in the form of numbers that are measurable and countable.

\section{a. Field Study}

Primary data are original data collected directly from its source and processed by the researcher (Sakaran, 2000). In this study, primary data was obtained directly from relevant sources and the researcher is the initial procurer and user of the said data. The survey in this research was conducted by distributing questionnaires. The questionnaires were used to collect primary data. These questionnaires were given to 55 permanent employees of Bank Syariah Mandiri Branch Office and Sub Branch Office Depok to measure their response on the variables of spiritual leadership and ETHIC organizational culture in BSM based on its dimensions and indicators. The Likert scale was used in the questionnaire. Both variables in the study were measured using the Likert scale.
The Likert scale is designed to analyze how strong a research subject agrees or disagrees with a given statement (Sekaran, 2000). The Likert scale employed in this research was a 6-point scale, from strongly disagree to strongly agree.

\section{b. Literature Study}

Secondary data are data which has been processed by other parties and is commonly in the form of publications (Sekaran, 2000). This secondary data was acquired by studying or analyzing various issues through books, documents, literature, or regulations as a guide for the researcher in determining theories that are relevant to the subject matter. As for data related to the company, the researcher obtained them from the official website of Bank Syariah Mandiri, as well as other sources directly, such as the company profile of Bank Syariah Mandiri, and several personnel data obtained from the Human Capital Division.

\section{Data Analysis Technique}

Descriptive statistics analysis and simple linear regression analysis were utilized in this study. Descriptive statistics analysis was used to illustrate the characteristics of the respondents and the average response given on the research variables by counting the mean. In order to portray the mean response of the respondents regarding the research variables, a new category with class restrictions calculated

Table 1.

\begin{tabular}{cccc}
\multicolumn{3}{c}{ Descriptive Statistics of Respondent Characteristics $(\mathbf{n}=\mathbf{5 5})$} \\
\hline \multirow{2}{*}{ Category } & & Frequency & Percentage \\
\hline \multirow{2}{*}{ Sex } & Male & 16 & $29 \%$ \\
& Female & 39 & $71 \%$ \\
Age & $22-24$ & 25 & $45.5 \%$ \\
& $25-30$ & 13 & $23.9 \%$ \\
\multirow{4}{*}{ Last Education } & $31-43$ & 17 & $30.9 \%$ \\
\multirow{4}{*}{ Work Period } & Diploma & 24 & $44 \%$ \\
& Bachelor's degree & 31 & $56 \%$ \\
& $1-2$ years & 30 & $54.5 \%$ \\
& $3-5$ years & 18 & $32.7 \%$ \\
\hline
\end{tabular}

Source: Result of processed data using SPSS 22.0 (2015) 
based on Sharma theory (2007) was made. The category consisted of very low (1.00-1.83), low (1.84-2.66), quite low (2.67-3.49), quite high (3.50-4.32), high (4.33-5.15), and very high (5.165.98). Subsequently, simple linear regression analysis was employed to examine the linear relationship between one independent variable $(X)$, spiritual leadership, with a dependent variable (Y), organizational culture. This analysis was undertaken to understand the direction in the relationship between the independent and dependent variables, whether it is positive or negative and to predict the value of dependent variable whether the independent variable experiences increase or decrease. The data was measured using an interval scale.

\section{Research Results}

\section{Descriptive Statistics Analysis}

The descriptive statistics analysis in this research was parted in two, namely descriptive statistics analysis for respondent characteristics and descriptive statistics for research variables. The descriptive statistics analysis of respondent characteristics can be observed in the table 1 .

Based on the descriptive statistics analysis above, it is known that the respondents in this study, who were permanent employees of Bank Syariah Mandiri Branch Office and Sub Branch Office Depok, were dominated by women, aged 22-24 years, possessing bachelor's degree, and working period of 1-2 years.

The descriptive statistics analysis of research variables was conducted by calculating the mean from the respondents' responses. As previously explained, the mean responses given by respondents were grouped into new categories based on the Sharma theory (2007) with certain class restrictions from very low to very high. The descriptive statistics analysis of research variables can be observed in the following:

\section{Table 2.}

Descriptive Statistics of Research Variables $(n=55)$

\begin{tabular}{llll}
\hline Variable & Dimension & Mean & Category \\
\hline \multirow{4}{*}{ Spiritual } & Vision & 4.98 & High \\
Leadership & Altruistic Love & 4.83 & High \\
& Hope/Faith & 4.99 & High \\
& Meaning/Calling & 5.26 & Very High \\
& Membership & 4.83 & High \\
& Total & 4.98 & High \\
& Excellence & 5.01 & High \\
Organizational & Teamwork & 5.07 & High \\
Culture & Humanity & 5.18 & Very High \\
& Integrity & 5.38 & Very High \\
& Customer Focus & 5.30 & Very High \\
Source: Result & of processed data & using & SPSS 22.0 \\
(2015) & & &
\end{tabular}

Based on the descriptive statistics analysis above, it can be known that the variable of spiritual leadership of the Head of BSM Branch and Sub Branch Office Depok is at a high category with a mean value of 4.98 and that in general, the employees of BSM Branch and Sub Branch Office Depok were of the opinion that the prevalent organizational culture is already very good since it is at a very high category with a mean value of 5.19 .

\section{Simple Linear Regression Analysis}

The result of the descriptive statistics analyses conducted in the previous passages has yet to answer the question of this study.

Table 4.

Correlation Coefficient

\begin{tabular}{|c|c|c|c|c|c|}
\hline \multirow[b]{2}{*}{ Model } & \multicolumn{2}{|c|}{$\begin{array}{l}\text { Unstandardized } \\
\text { Coefficients }\end{array}$} & \multirow{2}{*}{$\begin{array}{c}\text { Standardized } \\
\text { Coefficients } \\
\text { Beta }\end{array}$} & \multirow[b]{2}{*}{$\mathrm{t}$} & \multirow[b]{2}{*}{ Sig. } \\
\hline & $\mathrm{B}$ & Std. Error & & & \\
\hline $1 \quad$ (Constant) & 20.597 & 8.080 & & 2.549 & .014 \\
\hline SPIRITUALLEADERSHIP & .753 & .090 & .754 & 8.357 & .000 \\
\hline
\end{tabular}

a. Dependent Variable: ORGANIZATIONALCULTURE 
In order to answer the research question, simple linear regression analysis was used to understand how much influence does the spiritual leadership variable have on the organizational culture variable of Bank Syariah Mandiri Branch Office and Sub Branch Office Depok.

By using the SPSS 22.0 statistics program, the influence spiritual leadership has on organizational culture is subsequently known.

Table 3.

Model Summary of Simple Linear Regression

\begin{tabular}{lcccc}
\hline Model & $\mathrm{R}$ & $\begin{array}{c}\mathrm{R} \\
\text { Square }\end{array}$ & $\begin{array}{c}\text { Adjusted } \\
\text { R Square }\end{array}$ & $\begin{array}{c}\text { Std. Error } \\
\text { of the } \\
\text { Estimate }\end{array}$ \\
\hline 1 & $.754^{\mathrm{a}}$ & .569 & .560 & 6.48667 \\
\hline a. Predictors: (Constant), SPIRITUALLEADERSHIP
\end{tabular}

Source: Result of primary data processed using SPSS version 22.0 (2015)

Based on the table above, it is known that the $\mathrm{R}$ value result is 0.754 . According to Neuman (1994) a coefficient interval of $0.601-0.800$ bears strong relational ties, thus the relationship produced between the spiritual leadership variable and the organizational culture variable of Bank Syariah Mandiri is strong with an $\mathrm{R}$ value of 0.754 . Furthermore, the Adjusted R-Square value obtained is at 0.560 or $56 \%$ of the organizational culture variable can be explained by the spiritual leadership variable. In other words, $56 \%$ of ETHIC organizational culture at Bank Syariah Mandiri Branch Office and Sub Branch office is influenced by the spiritual leadership of the Head of Branch Sub Branch Office Depok, and that $44 \%$ of ETHIC organizational culture implementation can be explained by other factors.

Based on the table above, the hypotheses of this study are as follows, $\mathbf{H 0}=$ There is no influence of spiritual leadership on organizational culture at Bank Syariah Mandiri
Branch Office and Sub Branch Office Depok, H1 $=$ There is influence of spiritual leadership on organizational culture at Bank Syariah Mandiri Branch Office and Sub Branch Office Depok.

Upon observation of the table above, it is known that the significance of the spiritual leadership variable is at a value of 0.000 . Therefore, with a significance value of 0.000 $<0.05$, this leads to the conclusion that H0 is rejected and H1 is accepted. Additionally, the relationship between the two variables is found to be positive as signified with a value of 0.754 . Thus, it can be concluded that the spiritual leadership of the Head Branch of Bank Syariah Mandiri Depok Branch Office variable has a strong positive influence, as much as $56 \%$, on the ETHIC organizational culture of Bank Syariah Mandiri Branch Office and Sub Branch Depok.

\section{Discussion}

Based on the research results, it can be known that this study has similarities with previous studies in which spiritual leadership positively influences organizational culture (Engin Karadag, 2009; Seed Bakhsi, Younes Shahbazi, Saeed Jourbaniyan, Mehdi Afzaliharsini, 2013; Bulent Aydin, 2009). The spiritual leadership style of a leader influences the implementation of organizational culture, hence internalization of organizational values, vision-mission and objectives through culture can be properly employed, although it is undeniable that there are other aspects aside from leadership style that also influence the implementation of organizational culture at Bank Syariah Mandiri Branch Office and Sub Branch Office Depok.

The internalization of ETHIC organizational culture values undertaken by the head branch and the entire managerial staff upon all the employees is applied specifically in several activities at Bank Syariah Mandiri, covering: 


\section{Excellence}

The value of excellence is the first core value internalized into all BSM members. Excellence here means striving for perfection through integrated and continuous improvements. The dimensions found in this value are: perfection, ownership, result, prudence, competence. Excellence pose as the initial value to be encouraged as the management emphasizes in providing the best service quality in various BSM business fronts. The internalization process of excellence is applied in accordance to the dimensions it embodies. Firstly, regarding perfection, the cultivation of this value is conducted through various media, such as words of motivation referring to work perfection being placed in the work place. Additionally, superiors as role models become a key element in implementing work quality striving for perfection. What is meant by superiors here are the upper management personnel who should be providing ideal roles in terms of maximum work quality and should also constantly remind and motivate their staff to continually provide the best quality of work, as this would in itself raise customers' interest and make them feel comfortable with the services provided.

The second dimension is ownership, which means that all BSM members should have a high sense of belonging for the company, wherein they should feel ownership of BSM not only as a place where one works at, but also as a place where one undergoes life and conducts religious submission or ibadah to uphold Islamic religion by developing sharia economy in Indonesia. This is an understanding that has always been emphasized even from the time when these BSM employees were still under the status of candidates. When all employees have the same understanding regarding ownership of the company and their job, it is believed that their work will bring out the best results. The company cultivates the value of ownership through sharing moment sessions conducted routinely once a fortnight, and through morning prayers forum customarily held every day.

The following dimension in the core value of excellence is result. Essentially, the Human Capital Division (HCD) has a standard performance assessment format and undoubtedly all aspects are being examined, in terms of the accomplishment process up to the end result from the target tasked upon each of the employee. Nevertheless, BSM remains to put emphasis on results acquired from each of their employee's performance. There are monthly and trimonthly performance reports constantly monitored by the supervisor and $\mathrm{HCD}$, so there are clear reports regarding the performance results of employees. Reward and punishment are made available to prestigious employees and to those who are unable to reach the given target respectively. The cultivation of this result value is strictly employed via two means, namely through direct dissemination by the supervisor in each of the division, and through routine meetings with the directors. In addition, there is also annual work evaluation which shows the extent of targets and achievements accomplished by BSM. Implicit dissemination is also conducted during routine agenda of morning prayer forum. The next dimension is prudence, or cautiousness at work. The principle of prudence is established early on to all personnel of BSM, even before they were accepted as permanent employees in which they usually receive training and development materials for new employees. It is at that moment that the principle of prudence at the workplace is truly being internalized unto them. Prudence here means working meticulously, honestly and discreetly in maintaining company secrets so as not to be disclosed to those not privy of the information.

The final dimension from the core value of excellence is competence. What is meant by competence is the various capacity or 
competency necessary by an employee in conducting her/his job. BSM understands that in order to achieve company goals, all personnel must fulfill certain competence requirements. Their competence is examined periodically through a performance appraisal report which contains a number of assessment contents, namely: trimonthly achievements, along with competence/capacity (work quality, reliability, problem solving skills, and initiative), work culture relationship/behavior (ETHIC culture, customer service, cooperation, communication, discipline). The assessor's notes and suggestions as well as follow-up and recommendations on whether the employee would receive reward or punishment after the assessment are also found in the performance appraisal report. The reward is in the form of bonus, grade raise, promotion, change of status to permanent employee, and extension of work contract. As for the punishments, they are in the form of rotation/reassignment and termination of employment.

\section{Teamwork:}

The ability to develop a mutually synergizing work environment. The dimensions embodied in this value are respect, trust, communication, universality, social responsibility. Respect refers to appreciating time, system, and people. As professional bankers highlighting Islamic values, all employees must be appreciative of time, in terms of punctuality at the work place, taking appropriate breaks, and optimizing work during effective working hours; and must also show respect to the established system such as the reward and punishment system, determined routine agendas, the prevalent board of directors' decree, allocation of duties; they must also respect people, meaning they should respect their colleagues by providing mutual help and assistance, listen to directions from their superiors well, ask when answering, criticize and provide input directly, et cetera.
Trust is cultivated in all personnel in order to believe that the task given is in line with the job description and the given target can be accomplished appropriately. This trust is established to keep bad presupposition and suspicions among team members at bay. Communication in the team is also a dimension of teamwork, the management realizes that there is always great teamwork behind every great work, and behind every great teamwork there is always great communication among team members.

The following dimensions are universality and social responsibility. Universality here means that there are always background differences found within a team, be it education, ethnicity, or understanding and ideology. Even so, these differences should not be a point of dispute, a team should uphold the principles of universality and appreciate the various prevailing differences. Appreciating differences and upholding universal values as a form of team unity must be established. The final dimension in teamwork is social responsibility, which means that BSM as a team working together to achieve a goal must also consider the social responsibility it carries. The cultivation of these values that are relevant to teamwork are conducted through various means, initially through formal dissemination by superiors, then through initial team building for all new personnel, sharing moment, as well as through undertaking work project requiring mutual collaboration. Additionally, there is also award given to the best division based on their performance results hence honing the teamwork capacity of each division.

\section{Humanity:}

The third core value is humanity, which means upholding both humanitarian and religious values. There are two main dimensions embodied in this value, namely universality and social responsibility. It is not too different with the elaboration provided in the teamwork 
value, wherein essentially BSM is aware that the most important asset of the company is its human resource. Therefore, it is a given principle that in terms of work, humans should be humanized. The workers are not robots that are always ready to do their duties, they should be treated in kind according to values of humanity and religious principles. The internalization of this value is employed by creating a comfortable work atmosphere, and attempting to understand what the needs of the employees are. Throughout every morning prayer forum, there is spiritual sharing and elaborations on noble values we should uphold as human beings. In addition, throughout the working days there is always a moment every week to mutually share thoughts and conditions, spend quality time with superiors, and provision of various facilities the employees need such as day care facility at the work place for child rearing mothers, a properly arranged work environment, et cetera.

\section{Integrity:}

Integrity at the work place is the next core value that must be understood and properly internalized by all BSM members. Integrity here means abiding by the professional code of ethics and thinking as well as acting accordingly at work, and engaging in relations with colleagues or customers. The dimensions embodied in the core value of integrity are honesty, sincerity, discipline, and responsibility. Honesty and sincerity at work are two major foundations for establishing a high level of integrity. BSM since early on has always stressed the importance of honesty and sincerity at work, as well as having discipline and being prepared to be accountable for one's actions. All processes of recruitment and selection mechanism employed by BSM contain these dimensions, even in the employee's personal examination, integrity is one of the aspects highly regarded in the assessment. Following the recruitment process, the cultivation of integrity is conducted daily through an antifraud doctrine which is routinely dictated. Additionally, the management also provides directions and dissemination regarding integrity to employees during certain periods of time. This value is also cultivated by having the management as role models for integrity, as BSM is fully aware that one of the aspects in establishing a strong organizational culture is by having the management become role models for all employees. The management will subsequently become an ideal benchmark for other employees to follow or even surpass.

\section{Customer Focus:}

The final core value BSM strives to cultivate throughout the entire personnel is customer focus. This value of customer focus means understanding and fulfilling the needs of customers in order to develop BSM as a trusted and advantageous partner. The dimensions found in this value are customer satisfaction and innovation. Customer satisfaction becomes the main focus of BSM, and this is addressed by placing personnel with special skill sets in fostering relationships with others in frontline positions. BSM also strives to provide added values in services through several innovations. The cultivation of customer focus is conducted by implementing the smile, salutations, greetings and gratitude program. All BSM members, in conducting their daily activities, are also provided explanations regarding manners and etiquettes in speaking via the telephone with their business associates or customers. Frontline employees are specifically given special training to speak in front of customers with the necessary gestures and mannerism involved. As for back office staff, although they do not directly engage with customers, this does not mean that they lack customer focus value. Back office personnel remain obligated to resolve and assist in problems involving the customers and to provide the best service to customers having 
issues with BSM. In order to cultivate a strong organizational culture throughout the entire organization, BSM utilized tools which are ritualistic and conducted repeatedly such as joint prayers, dictation of vision -mission, personnel rules and regulations, reading of BSM self values namely ETHIC (Excellence, Teamwork, Humanity, Integrity and Customer Focus), reading of the anti-fraud doctrine, joint religious study along with religious sermons by the management or staff, and sharing sessions.

Organizational culture is the social glue, a unification of identity and standards of what should be done and said by employees, and it becomes a sense-making mechanism which controls, guides and shapes the attitude and behavior of employees (Robbins, 2003). Therefore, the implementation of organizational culture in the company's daily activities is of utmost importance. Based on the regression test research results, it is known that spiritual leadership has 56\% influence on the implementation of ETHIC organizational culture employed by Bank Syariah Mandiri Branch Office and Sub Branch Office Depok. This means that the leadership style of the Branch Head has quite a significant influence on the implementation of ETHIC organizational culture and this should be maintained and enhanced. Whatever the case, the role of the leader in determining the organization's operation is very substantial particularly in the efforts of internalizing the prevailing organizational values, vision, mission and culture.

However, it should be noted that there is $44 \%$ of other aspects aside from leadership style which influence the implementation process of organizational culture. According to Robbins (2003), other elements influential in establishing organizational culture other than role model leadership, are ceremonies or rituals that are often held within the organization. In the case of Bank Syariah Mandiri, this is achieved by having daily activities conducted routinely early in the morning, namely the morning prayer procession along with words of motivation from the leader, sharing of current development at work, as well as appreciative acknowledgement to prestigious employees. Robbins (2003) also states that the implementation of organizational culture is also influenced by the operational environment of the company. This seems to also be one of the aspects which strengthens the implementation of ETHIC organizational culture at Bank Syariah Mandiri Branch Office and Sub Branch Office Depok. In the main hall, lobby, as well as the employee's work stations, we can find photos bearing elaborations on the ETHIC culture, and there are also information boards easily visible by employees that show the values, goals, vision and mission of the company. This will indirectly accustom employees to easily internalize the existing company culture and values.

Bank Syariah Mandiri also has a particular behavior when engaging in everyday interactions which is by greeting people, being gentle and kind, and smiling. This, according to McKenna and Nic Beech (2000), serves as one of the factors which also influences the process of organizational culture cultivation in a company because there is a cultivation of mutual identity that is constantly undertaken through particular mannerisms during interactions. According to Robbins (2003) another aspect that also influences the formation of organizational culture refers to network or informal communication network within the company conducted by employees, hence companies that create a flexible system which enables good informal communication to happen facilitate in the process of disseminating organizational culture values.

\section{Conclusion}

This study aims to answer the proposed research question regarding the influence 
of spiritual leadership on organizational culture at Bank Syariah Mandiri Branch Office and Sub Branch Office Depok. Based on the conducted research, it can be concluded that spiritual leadership has a strong influence on the implementation of ETHIC organizational culture at Bank Syariah Mandiri Branch and Sub Branch Office Depok.

Based on the conclusion, it is suggested that Bank Syariah Mandiri conducts a periodic assessment of branch head, not merely regarding the level of branch office performance accomplishments, but also regarding how the employees view the head of the branch in leading the office. This is aimed at potentially maintaining the quality of the Branch Head in interacting and cultivating company culture, values, and vision-mission to the employees, bearing in mind that the head of the branch has quite a substantial influence on the implementation of the company's organizational culture. Additionally, there should also be an agenda of periodic capacity building program provided for the head of the branch office.

\section{References}

Baron A Robert, Jerald Greenberg. (1997), Behavior in Organizations: Understanding and Managing the Human Side of Work. New Jersey: Prentice-Hall International.

Cooper, W. F. \& Schindler, P. S. (2001). Business Research Methods. New York: McGrawHill Publishing Company

Hofstede, G. 1991. Cultures and Organizations: Intercultural Cooperation and Its Importance for Survival. London: Herper Collins Publisher.

Kotter J.P \& Hesket J.L. 1997. Dampak Budaya Perusahaan terhadap Kinerja. Jakarta: Prenhalindo

Robbins, Stephen P. (2008). Perilaku Organisasi. Jakarta: Salemba Empat.
Schein, Edgar H. (2004). Organizational Culture and Leadership. San Fransisco: The JosseyBass business \& management series.

Sekaran, Uma. (2000). Research Methods for Business: A Skill-BuildingApproach. New York: John Wiley and Sons.

Shani, Lau. (2005). Behavior in Organizations an Experiental Approach. New York: Mc Graw.Hill International Edition.

Sharma, JK. (2007). Business Statistics, Second Edition. India: Dorling Kindersley Pvt. Ltd.

Siagian, Sondang P. (1995). Teori Motivasi dan Aplikasinya. Jakarta: Rineka Cipta.

Urbina, S. (2004). Essentials of Psychological Testing. New Jersey: John Wiley \& Sons.

\section{Scientific Publications:}

Claude, Jean, Garcia Zamor. (2003). Workplace Spirituality and Organizational Performance, Public Administration Review, 63(3), pp. 355-363.

Collin dan Porras dalam Eve Poole. (2009). Organizational Spirituality - A Literature Review. Journal of Business Ethics, 84(4), pp. 577-588.

Erkutlu, Hakan. (2008). The Impact of Transformational Leadership on Organizational and Leadership Effectiveness the Turkish Case. Journal of Management Development, 27(7), pp. 708-726.

Fleenor, John W. (2006). Trait Approach to Leadership. Encyclopedia of Industrial and Organizational Psychology. 2006. SAGE Publications.

Frisdiantara, Christea; Sahertian, Pieter. (2012). The Spiritual Leadership Dimension in Relation to Other Value-Based Leadership in Organization. International Journal of Humanities and Social Science, 2(15), pp. 284-290.

Fry, L.W, et al. (2005). Spiritual Leadership and Army Transformation: Theory, Measurement, and Establishing a Baseline. 
The Leadership Quarterly, 16(5), pp. 835-862.

Fry, L.W, Melanie P.Cohen. (2008). Spiritual Leadership as a Paradigm for Organizational Transformation and Recovery from Extended Work Hours Culture. Journal of Business Ethic, 84(2), pp. 265-278.

Fry, L.W. (2003). "Toward a theory of spiritual leadership". The Leadership Quarterly, 14(6), pp. 693-727.

Fry, L.W, Laura L.MatherlY. (2006). Spiritual Leadership and Organizational Performance: An Exploratory Study. Tarleton State University-Central Texas.

Judge, Timothy A, et al, 2006 "Charismatic and Transformational Leadership A Review and Jung, T, T Scott, HTO Davies, P Bower, D Whalley, R McNally, \& R Mannion (2007), Instrument for the Exploration of Organizational Culture, Working Paper

KARADAG Engin. (2009). Spiritual Leadership and Organizational Culture: A Study of Structural Equation Modeling. Educational Science: Theory \& Practice 9 (3), pp. 13911405.

Mitroff, I. I., \& Denton, E. A. (1999). A spiritual audit of corporate America: A hard look at spirituality, religion, \& values in the workplace. San Francisco, CA: JosseyBass.

Odumeru, James A, (2013).Transformational vs. Transactional Leadership Theories: Evidence in Literature. International Review of Management and Business Research, 2(2), pp. 355-361

Poole, Eve. (2009). Organizational Spirituality -A Literature Review. Journal of Business Ethics, 84(4), pp. 577-588.

Reave, Laura. (2005). Spiritual values and practices related to leadership effectiveness. The Leadership Quarterly, 16(5), pp. 655687.

Sadeghifar, Jamil, Mohammad karim Bahadori, et al. (2014). Relationship between Career Motivation and Perceived Spiritual Leadership in Health Professional Educators: A Correlational Study in Iran. Global Journal of Health Science, 6(2), pp. 145-154.

SeedBakhsi, Younes Shahbazi, et al. (2013). Inquiry of the Relationship between Organizational Culture and Spiritual Leadership in Govermental Organizations in Kermanshah. Advances in Environment Biology, 7(10), pp. 2899-2905.

Shankar, Badrinarayan Pawar. (2014). “Leadership Spiritual Behaviors Toward Subordinates: An Empirical Examination of the Effects of a Leader's Individual Spirituality and Organizational Spirituality". Journal Business Ethic, 122(3), pp. 439-452.

Smith, Carol, The Greenleaf Centre for ServantLeadership UK (2005). Retrieved November 12, 2005

Spirituality and Business Author(s): Donal Dorr Source: The Furrow, Vol. 51, No. 7/8 (Jul. - Aug., 2000), pp. 421-426 363 di unduh 19 Februari 2014 dari www.jstore.org Yong, Brenda, Relationship Between Emotional Intelligence, Motivation, Integrity, Spirituality, Mentoring and Servant Leadership Practice. Arts and Social Science Journal, 4(2013), pp. 1-6.

\section{Electronic Publications:}

http://syariahmandiri.co.id/category/ penghargaan/ accessed on Friday, 23rd of May 2014

http://www.kemenkeu.go.id/Berita/biperbankan-syariah-berkembang-pesat accessed on Friday, 21st of February 2014

http://www.bi.go.id/id/perbankan/syariah/ accessed on Tuesday, 25th of February 2014

http://pustaka.unpad.ac.id/wp content/ uploads/2009/09/instrumen_pengukuran_ motivasi.pdf downloaded in the 4 th of March 2014 
http://www.statsdata.my.id/2011/12/ujivaliditas-dan-reliabilitas.html, accessed at 11.30 Tuesday, 6th of May 2014

http://elearning.gunadarma.ac.id/docmodul/ diklat_kursus_spss/d.Bab_II_Uji_Validitas_ dan_Uji_Reliabilitas.pdf http://www.saylor.org/site/wp-content/ uploads/2013/02/BUS208-3.3.9.1-ValuesBased-Leadership-FINAL.pdf accessed at 14.28 Tuesday, 10th of February 2015 